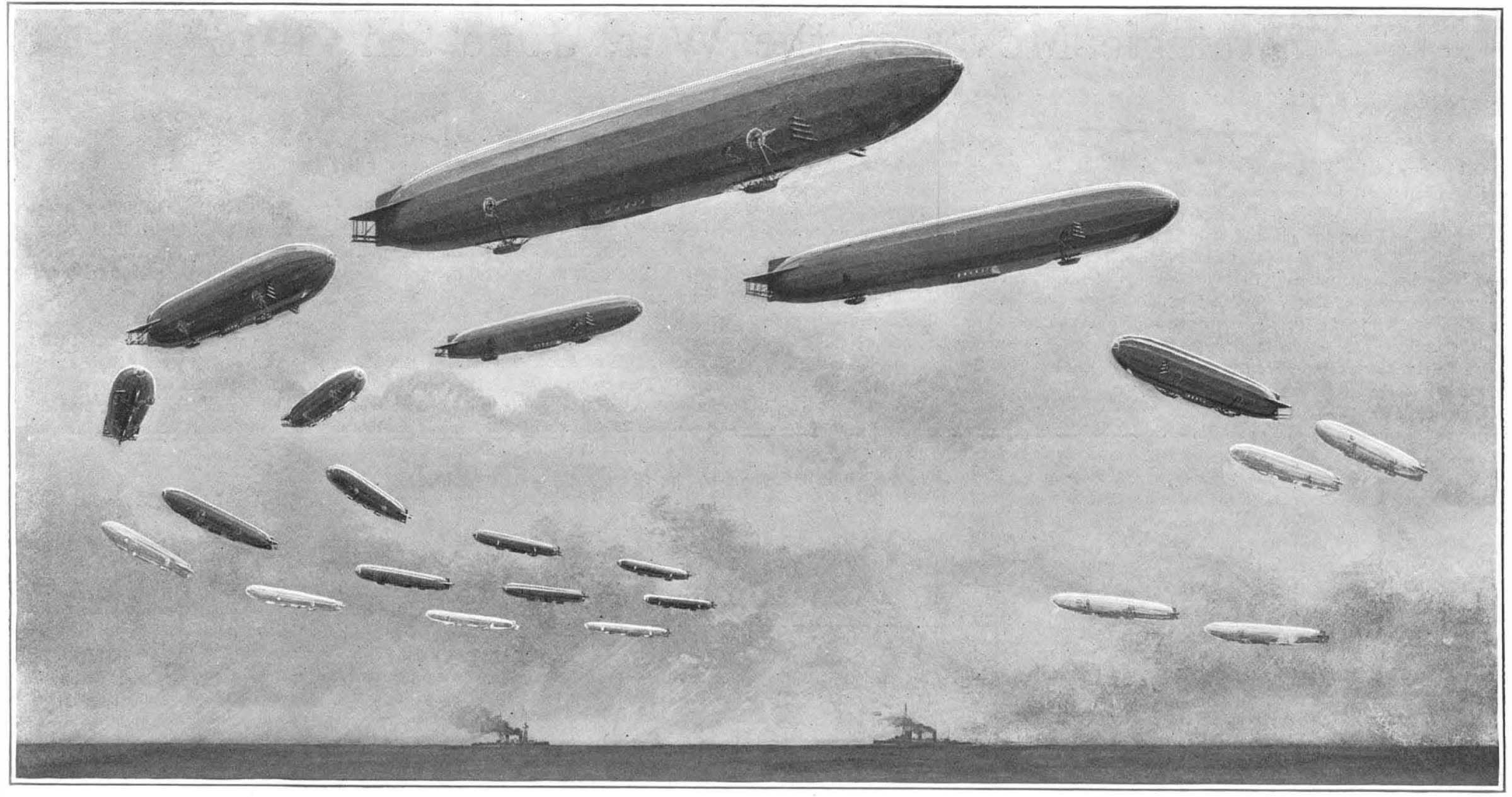

Comparative Zeppelin strength of Germany, France and Great Britain at the outbreak of the war. On the left, thirtoen German ships in commission and four (in white) building; on the right, above, one French ship built and two building; on the right, below, two Britioh ships building

\title{
Mastery of the Air vs. Control of the Sea
}

\section{Zeppelins as Observation Towers for the German Fleet}

By Baron Ladislas d'Orcy, Member, American Institute of Aeronautical Engineers

THERE is such a thing as air power. When a squadron of German Zeppelins* is capable of crossing the 400 odd nautical miles which separate Germany's North Sea coast from English shores, when it can discharge two tons of shells per vessel, ward off British fighting aeroplanes and safely return to port without being seriously interfered with-which is mostly the case - then that airship squadron indubitably proves the existence of air power.

Sea power is chiefly a matter of construction, training and numbers; so is air power. Only a fleet comprising ressels of all types in due proportion can effectively exercise sea power; the same rule applies to air powe To rely only upon aeroplanes and anti-aircraft guns for fighting Zeppelins is just as contrary to sound military science as it would be to intrust the defense of a maritime country entirely to coast batteries and mosquito craft.

To be sure, air power does not yet impose itself with as overwhelming a force as sea power; but this is due only to t, being still in the initial stage of their development cannot yet fully exercise the functions for which they are ultimately intended. Some future day air power will surely dispute sea power and finally become supreme; and there are already indications at hand where air power is beginuing to overlap on sea power.

By opposing faster and heavier-gunned battle cruisers and a larger number of dreadnaughts to those of Germany, Great Britain has paralyzed German shipping and has bottled up the Kaiser's High Sea Fleet in the Kiel Canal: she thus rules the seas. Still an inferior German battle cruiser squadron succeeded several times in raiding English coast towns, escaping-save once without being intercepted and forced to fight. Why? Simply because while England rules the seas, Germany rules the air above the seas, or more correctly speaking the air above the North Sea.

Great Britain has no Zeppelins, i. e., rigid airships capable of great endurance, for reconnoitering the North Sea; and as seaplanes do not possess a radius of action

sufficient to carry out this duty, Sir John Jellicoe's Grand Fleet has to rely on its 30-knot scout cruisers, whose range of vision is limited to 20 miles, for gathering information about the enemy's whereabouts. Observation balloons and kites offer but poor substitutes for long range airships, whose speed and movements are independent from naval vessels, whereas balloons and kites are anchored to their mother ship and there-

GERMANY (Builtand building: 31 airships of 742.7 grosstons.) Commissioned:13 airships (312 gross.tons.) Building 4airships (II0.8 gross fons) Previously built.scrapped or lost 14airships(319.9g.t.)

GREAT BRITAIN (Builtand building: 3airships of 76.6 gross tons) None commissioned Building 2 airships ( 54 gross
Previously built. lost : lairship (22.6 gross tons)

FRANCE (Built and building:2 2airships of 63.5 gross tons.) Commissioned lairship (18.5 gross tons)
Building: 1 airship(45 gross tons) Unofficially reported.

NOTE- For sake of convenience all rigid air ships are listed above as Zeppelins; Tonnage,expressed gross or total lift. which furnishes a betfer basis of comparison than volume.

Table showing comparative strength of the Zeppelin fleets of Germany, Great Britain and France on August 1st, 1914

fore are largely dependent on the latter's speed. Now turning to the German "system" we find that fleet escorted by Zeppelins, flying at a height of 5,000 feet and at a speed of about 60 knots, can detect the enemy at a distance of 80 miles, $i$. $e$, at a range the rimes at a distace of 80 miles, $i e$ at a rane thereby for the Germans has well been illustrated by the latest naval raid on Lowestoft, where, owing to their scout airships, the Germans were able to keep at a safe margin from the British battle cruiser squadron's ever-watchful "eyes." Such is the influence of air power upon sea power. This extraordinary situation, where a fleet, gun for gun and ship for ship the superior of its foe, cannot prevent the latter-for lack of swift information-from raiding the shores of the country which is top dog on the sea, makes it worth while to examine the underlying causes which brought about this condition.

For the past ten years the great military nations of Europe were all engaged in building up airship fleets; but it seems, in the light of subsequent events, that Germany alone realized from the beginning the exact nature of the advantages a persistently followed up airship molics would confer upon her military and naval seemed chiefly concerned with the development of the aeroplane, convinced as they were that a fleet of such mosquito craft would quickly be able to put out of action any " gasbag," as airships were contemptuously referred to by their detractors.

Still, for some time it looked as if France, and, to some extent, Italy too, were determined to meet Germany's steadily growing airship fleet in the only way that might have put them on equal footing with the aerial forces flying the black-crossed ensign : by matching airship with airship. But if such was their object, both Latin countries were badly ject, both Latin handicapped in this realization by a policy the building of non-rigid and semi-rigid airships exclusively, these types being national products, while it barred vessels of the rigid type for the sole reason that the latter had been originated in Germany.

The Germans had no auch scruples. hile Count Zeppelin was exerting every effort to improve his airships, the German army authorities tried to purchase in France one airship each of the semirigid Lebaudy and the non-rigid Astra types. Having failed to achieve their object the Germans resolved to copy the vessels they could not buy: this is how the Gross-Basenach and Parseval airships came into being. It is but eair to add that since this "ingpired" inception, vessels of the above named types have largely developed upon original lines. 
LEGAL NOTICES

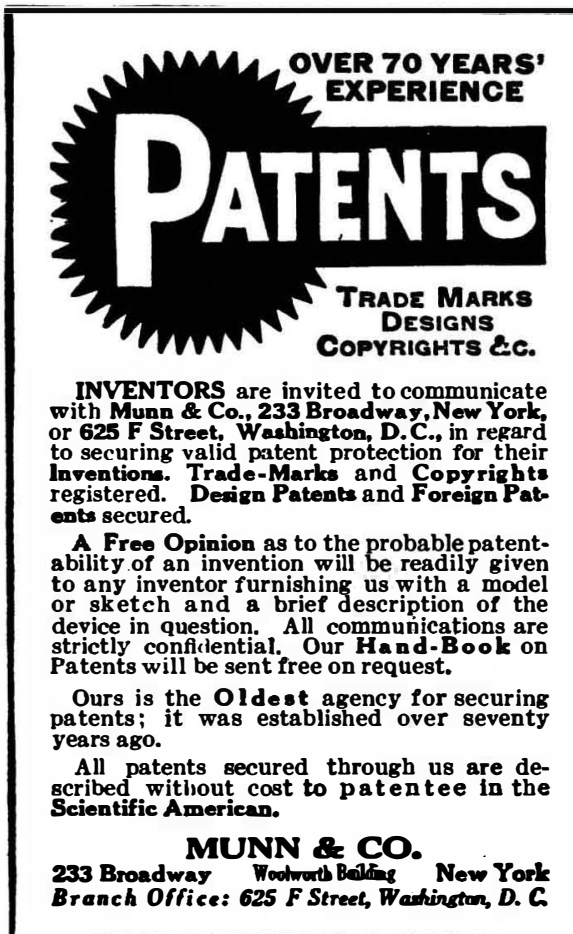

Annual Subscription Rates for the Scientific American Publications

Subscription one vear.......................83.00
Postage prepaid in United States and possessions,

Postage prepaid in United States and possessions,
Mexico, Cuba and Panama.

Subscriptions for Foreign Countries, one year,
postage prepaid............................50 Subscriptions for Canada, postage prepaid ..... 3.75

The Scientific American Publications Scientific American (established 1845).......... $\$ 3.00$
Scientific American Supplement (established

The combined subscription rates and rates to foreign
countries, including Canada, will be furnished

upon application.
Remit by postal or express money order, bank

draft or check.

Classified Advertisements

Advertising in this column is 75 cents a line. No les
than four nor more than 12 lines accepted. Count
geven words to the lin e. Allorders must be accomponied

than four nor more than 12 lines accepted. Cou
geven word totothe lin e. Allorders muat be accompiani
by a remittance.

A WONDERFUL DISCOVERY

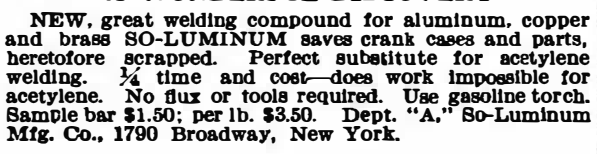

AGENTS WANTED

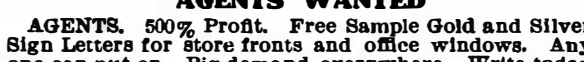
one can put on. Big demand everywhere. Write toda

BUILD GRANDFATHER'S CLOCYS

WE FURN GH FREE blue prints and Instruction

town, Phlladelphla.
PATENT FOR SALE

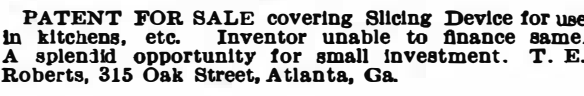

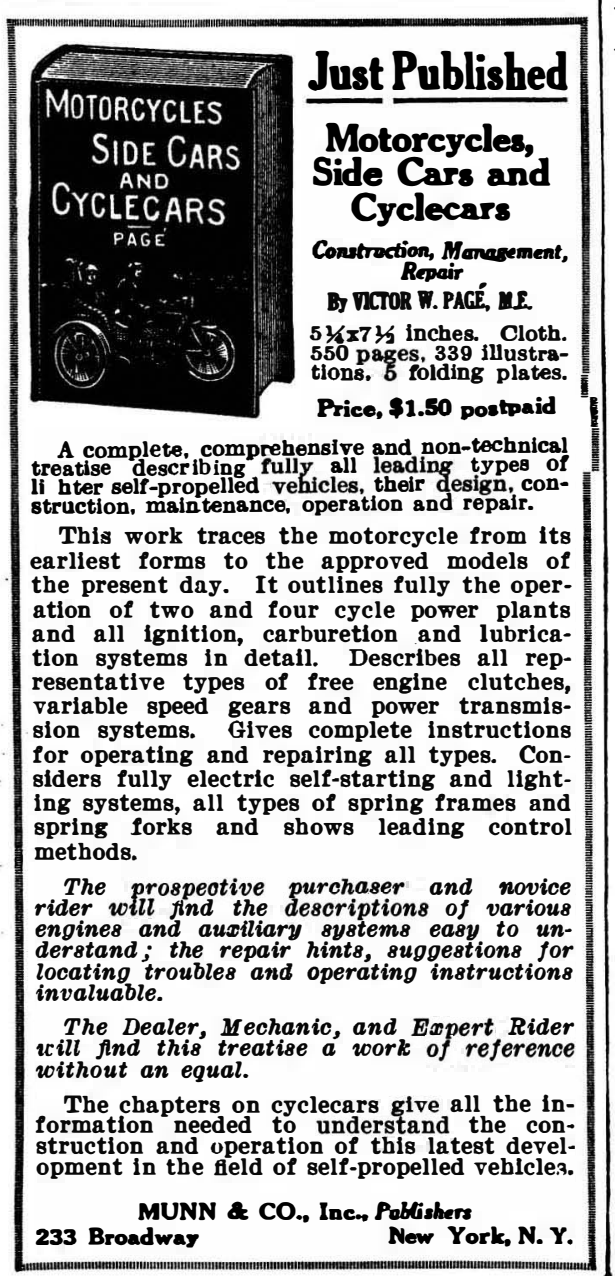

Shackleton's South Polar Expedition Concluded from paye 636 ) his reason the winds to be observed on the margin of this anticyclonic area will display a more or less cyclonic character, according to the year taken into consideration.

The Weddell Sea east of Graham Land, as well as the Belgica Sea west of Graham Land, belong precisely to this region of very accentuated variations. The Weddell sea probably more so than the Belgica Sea, and that is why the ice conditions of the Weddell Sea may differ so greatly.

Shackleton's scientific observations will therefore be most valuable.

From another purely scientific point of view it is to be regretted that Shackleton did not succeed in accomplishing his programme. I have in mind the problem of the Antarctic Andes. It was my pleasure to discover, in 1898 , that the rocks of Danco Land, of Palmer Archipelago and of Graham Land were Andean rocks. The great physiographic similarity of this Antarctic chain of mountains and the southern Andes of Terra del Fuego also led me to the supposition that the Andes really reappear in Antarctica south of Cape Horn. This view has since been adopted by all students of Antarctic geology.

But South Victoria Land, on the opposite side of Antarctica, is geologically and physiographically absolutely different: it is an old table-land.

In what direction do the Antarctic Andes extend? It may be that this rela. tively recent curves west towards King Edward VII Land, or it may be that it bifurcates, as has been presumed by Edgeworth David. This important problem justified the atrom sea to sea.

Mastery of the Air vs. Control of the Ses

Concluded from page 637)

The German authorities seem to have been quite aware that in spite of their limitations the non-rigid and semi-rigid airships could fulfill some functions to the satisfaction of their owners-chiefly n conjunction with army operations and harbor defense, where their ease of transportation, low cost and general handiness were greatly appreciated. But the Germans were none the less convinced that for strategical reconnaissances and chiefiy naval scouting high-speed airships, capable of long endurance, were required and that these requirements could not be attained by either one of the above mentioned types. This is why, undaunted by countless accidents, many of them tragic, Germany never lost her faith in the Zeppelin and, what is more, even encouraged the development of another type of rigid airship, the Schütte-Lanz. Thus, when the German navy lost her first two Zeppelins, four new vessels were laid Zeppelins, four new vessels were laid
down at once, three of them at the Zeppelin factory and one at the SchitteLanz works.

It is interesting to compare this progressive policy-which at the time was called adventurous-with the hesitating attitude of the British authorities towards airships in general and Zeppelins in particular.

After having tried and, generally speaking, failed to produce a serviceable lighterthan-air machine of original design, the War Office-which up to 1914 was alone in charge of the airships-purchased from foreign manufacturers a number of nonrigid and semi-rigid vessels, while the Royal Aircraft Factory furnished some small airships for instruction purposes.

The Admiralty seemed for a short time to be animated by a more progressive spirit. In 1909 an order was placed with the well-known shipbuilding flrm of Messrs. Vickers, Sons and Maxim for a 21-ton airship of the Zeppelin type. This vessel, the "Mayfly" was launched two years later, but unfortunately broke up while she was being towed out of her shed. As it proved impossible to repair the

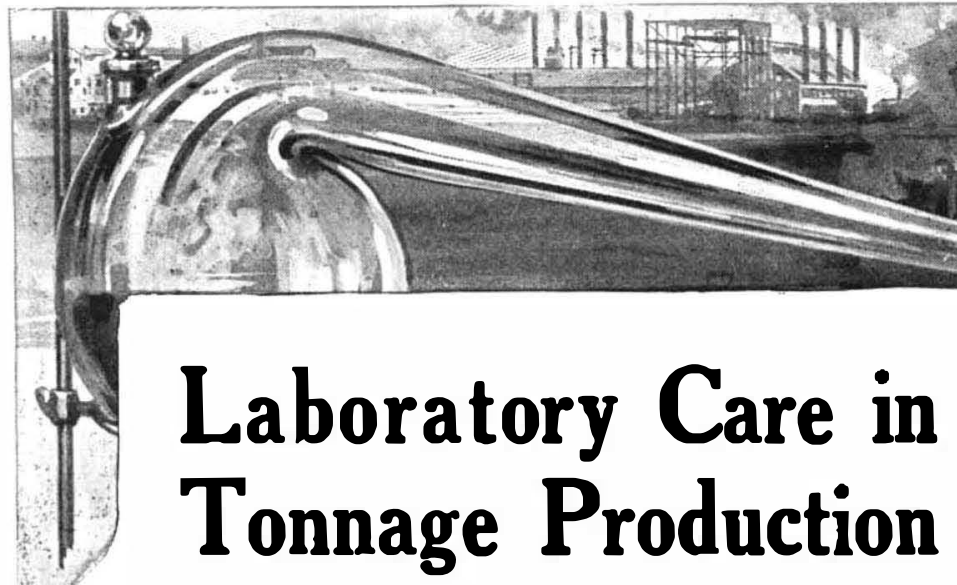

From furnace to shipping platform, Armco (American Ingot) Iron is under scientific and conscientious care.

It is, as a result, not only pure, the purest iron made, but the most nearly perfect in evenness, the elimination of gas bubbles, and in all the qualities that render it superior for enameling, galvanizing and polishing.

\section{ARMCO IRON Resists Rust}

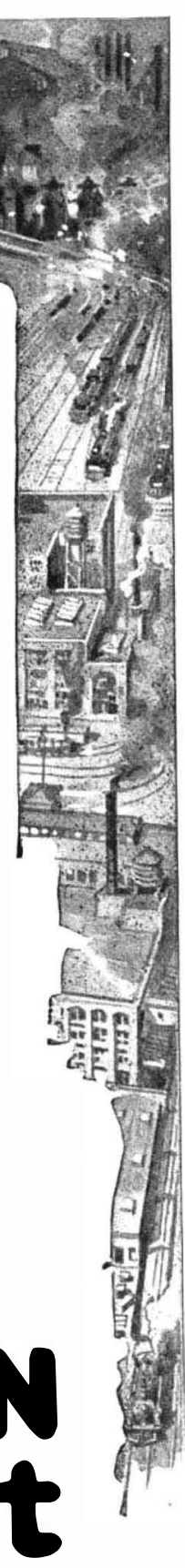

Is the great truth, but other properties also are strong recommendations for its use.

Armco Iron reduces factory loss through culls, defective welds, enameling, etc.

Because of its powerful combination of merits Armco Iron is used in large quantities by such firms as the Grand Rapids Refrigerator Co. in the Leonard Cleanable Refrigerator; the Enameled Tank Co., Kalamazoo, in Porcelain Enameled Closet Tanks, and by over seventyfive leading stove manufacturers.

If you have any trouble securing products of Armco Iron, write to us and we will see that you get what you want. If you are a manufacturer, get full information as to how Armco Iron cuts factory losses.

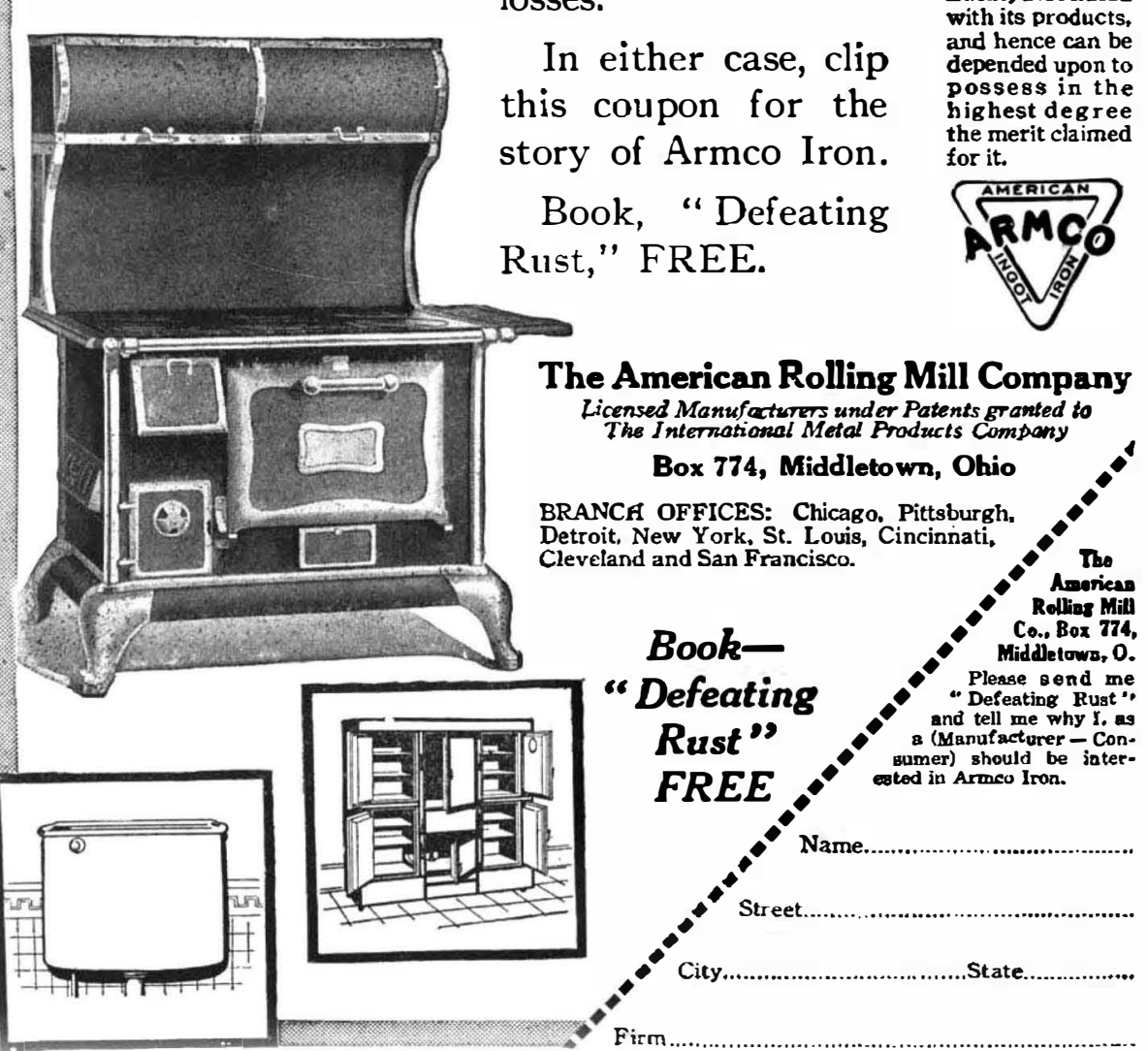



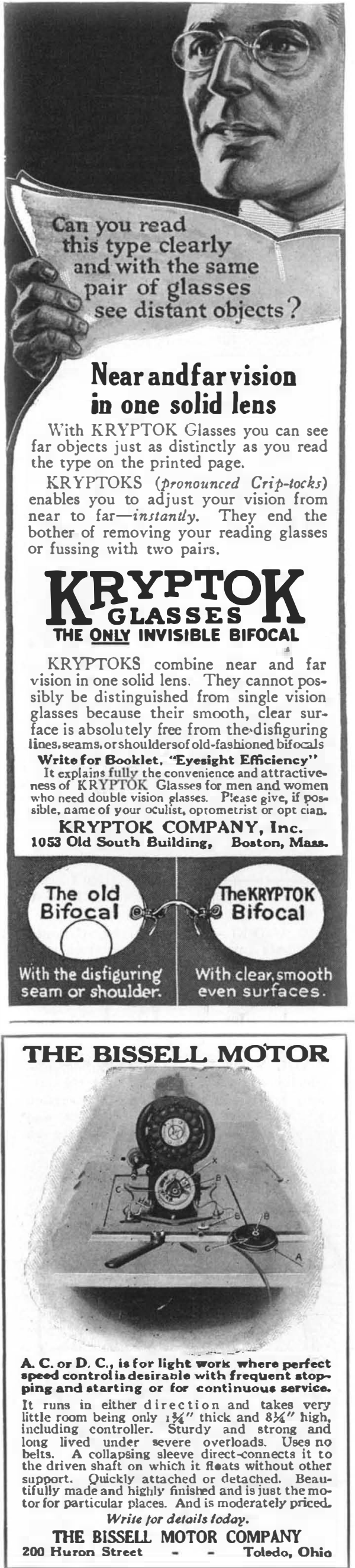

Rose Polytechnic Institute

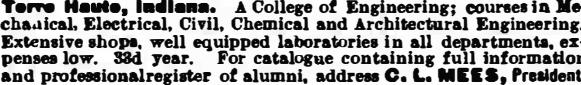

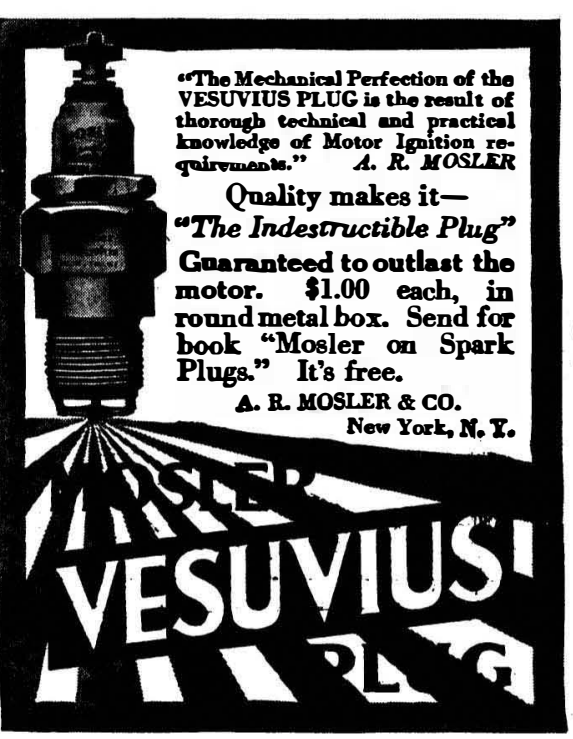

"Mayfly" and no credit was available for stopped experimenting with Zeppelins until 1914, when Mr. Winston Churchill became First Lord of the Admiralty. At the instance of this far-seeing minister, twelve airships were laid down at once, two of which were Zeppelins; but before this building programme could be carried By this thirteen Zeppelins and half a dozen minor airships, while Great Britain possessed but three small non-rigid vessels.

It is rather astonishing that the British naval authorities should not have realized any sooner the value of airships and, particularly, of Zeppelins for naval scouting. In 1909 Sir Percy Scott-many of whose "revolutionary" predictions regarding naval constructions have been vindicated by the great war-wrote, in a preface to Jane's All the World's Airships, the following prophetic words: "In gaining information of the locality, strength and disposition of the enemy's fleet and so possibly unmask his strategy airship's services would be invaluable, for it might not be possible to obtain the information in any other way."

Twenty-two months of warfare have fully demonstrated the truth of Sir Percy's assertions. Germany has been able to use her Zeppelins with marked success in many diverse functions, about which little has come to light as yet. It is noteworthy, howevar, that one Zeppelin was decorated with the Iron Cross " for coöperation with submarines during a successful attack on three British armored cruisers." Several Zeppelins have also coöperated with German submarines, for enforcing the so-called "submarine blockade" by stopping and occasionally sinking such merchantmen as they could oring Into a German port. Other the German shores from Holland to Denmark and from Denmark to Russia ; still others have played an all-important rôle as fast scouts for such portions of the German fleet as have ventured beyond the range of Heligoland's coast batteries. Their participation in the latest naval raid on Lowestoft even raises the question, whether the twofold slipping of the British blockade by the German commerce raider "Moewe" may not be attributed to intelligent coöperation between her skipper and one or more Zeppelins. The high speed of these airships, and their faculty to send, as well as to receive, wireless messages makes this assumption appear quite plausible.

German official reports seem to omit purposely all reference to this sort of work done by Zeppelins, while particular emphasis is laid on the destruction achieved by Zeppelin raids against the British Isles. These incursions on undefended shipping and manufacturing towns -however contrary to laws of civilized warfare they be-come well within the German definition of " commerce war," as practiced by German naval forces on several occasions. ("Vide" the raids on Scarborough and Lowestoft, the bombardment of Madras by the "Emden" and that of Papeëte (French Oceania) by Admiral von Spee's squadron; the latter instance is particularly enlightening, as all the shells were deliberately aimed at the business section of that port.)

From a military viewpoint the Zeppelin raids on England are of comparatively small importance, though some of them may have served the purpose of a "reconnaissance in force," either for ascertaining the whereabouts of Sir John Jellicoe's Grand Fleet or else for reconnoitering the location of English coast defense works. If such really was their purpose, then the dropping of bombs was successful from the German point of view, as it forced the British to disclose the location of their batteries by firing on the air raiders.

There still is another important function which Zeppelins may fulfill with a fleet: gun-spotting. During the Gallipoli campaign the "Queen Elizabeth" repeatedly fired across the peninsula, hitting targets invisible to her gunners, the cor(Concluded on puge 649)

Why Motors Grow Noisy

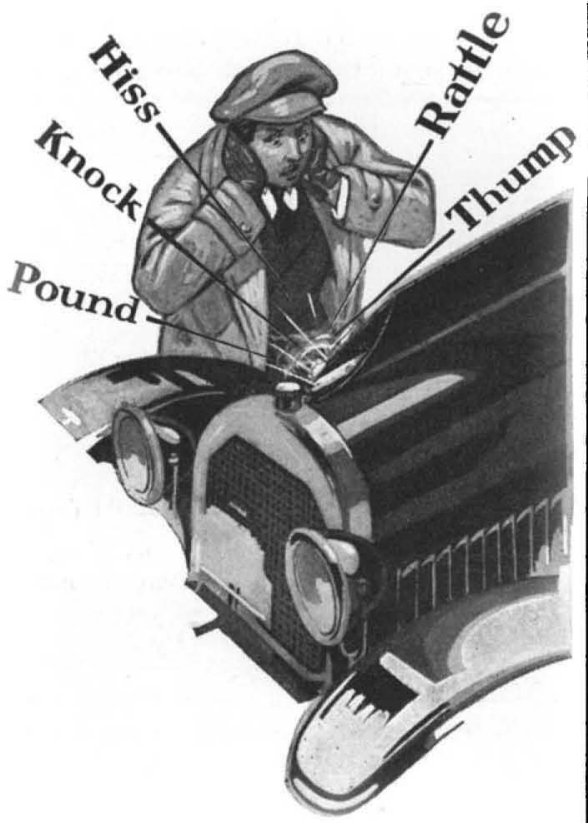

The new car purrs quietly along the road.

But gradually the purr of the new motor gives way to a noise here and a noise there.

The most common cause is friction.

Friction is relentless. Gradually it wears down the moving metal parts. Snug fits become loose fits.

The common cause of premature motor noise is incorrect lubricating oil.

Surely there is quite enough for you to learn about the operation of your car without experimenting with so serious a matter as lubrication.

To illustrate the complexity of the problem:

The Vacuum Oil Company manufactures about 350 different oils. Each is an excellent oil for its purpose.

But the thick, black oil which is required for the cylinders of a railroad locomotive, where carbon is not a factor, or the thin, light oil needed for the lubrication of a sewing machine would each be entirely unfit for an automobile motor.

And oils suited to one automobile motor are too often entirely unsuited to another.

For 50 years we have specialized in lubrication. In our study of the automobile motor we have found that each make and model presents a distinct lubrication problem demanding scientific analysis.

The Lubrication chart at the right which represents our professional advice, has for a number of years, been a standard guide to correct au tomobile lubrication. You may be assured that the oil really scientific lubrication-your greatest protection against premature motor noises, which means premature wear.

If your car is not listed at the right a copy of our complete Lubrict
will be sent you on reques. In buying Gargoyle Mobiloils from your
dealer, it is gafest to purchase in orizinal packe-

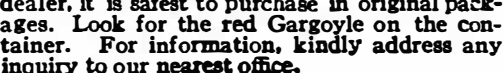

VACUUM OIL COMPANY, Rochester, N. Y., U. S. A. Specialists in the manufacture of high-grade lubricants for

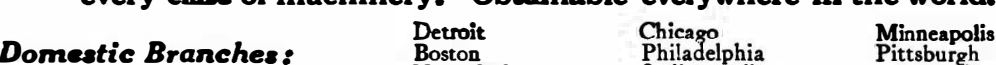

Correct Automobile Lubrication Explanation:-The four grades of lubrication, purified to remove free carbon, are:

Gargoyle Mobiloil "A" Gargoyle Mobiloil "B", Gargoyle Mobiloil "Arctic"

In the Chart below, the letter opposite the car indicates the grade of
Gargoyle Mobiloils that should be used. For example "A" means Gar-
goyle Mobiloil "A." "Arc" means
Gen Gargoyle Mobiloil "Arctic." etc. The recommendations cover all models of both pleasure and comm
unherwise noted.

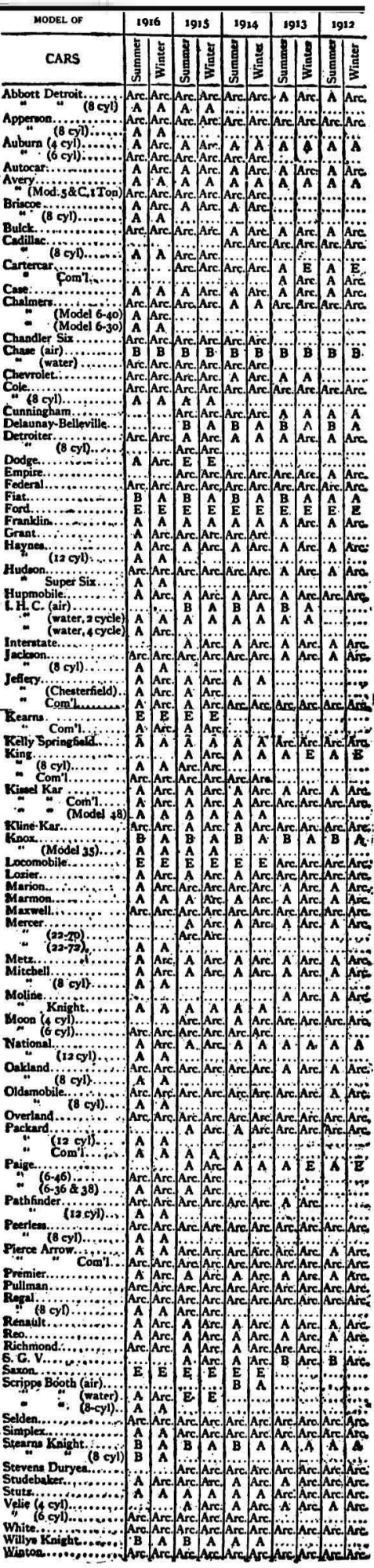

Electric Vehicler For motor bearings and

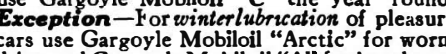

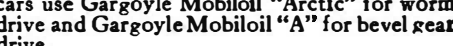

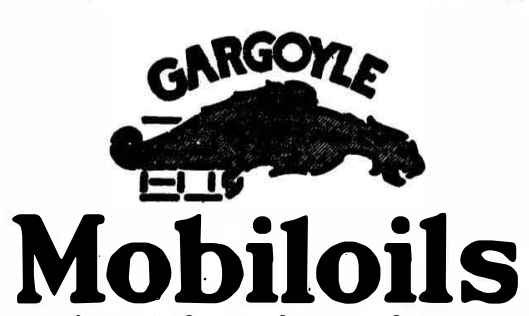

aradefor each type of motor

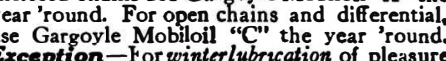



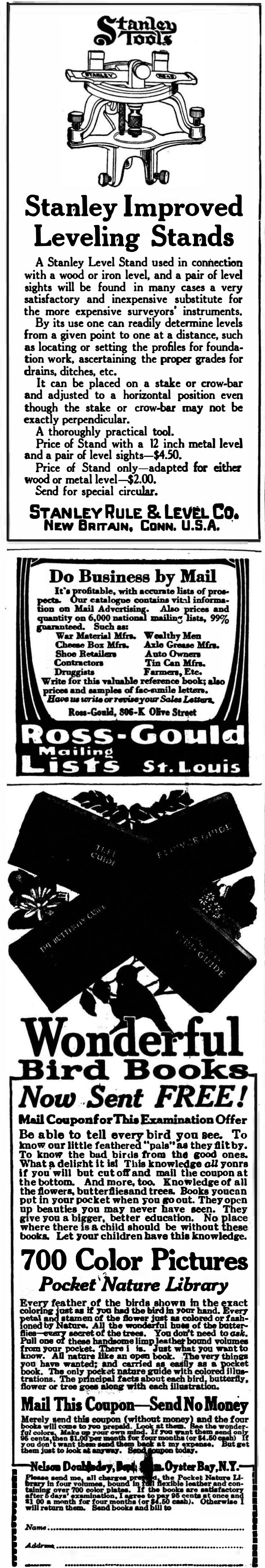

rect range being given by seaplanes through wireless.

But seaplanes cannot ret-on account of their short radius of action-cruise with a fleet out to sea; it is true that they might be carried on motherships, but in this case their movements will be dependant on their floating bases, whereas Zeppelins may cover 1,000 nautical miles independently. The advantage then lies obviously with the airship, the more so as the latter might spot the guns while remaining stationary and send, as well as receive, wireless messages-things a seaplane cannot do.

The British Admiralty seems to have at last awakened to the realization that Zeppelins constitute excellent naval scouts and that a lack of them places a fleet in an appreciable handicap against an enemy possessing such airships. This view was frankly voiced by Mr. Balfour, First Lord of the Admiralty, in the House of Commons.

"It is extremely desirable that we chould have lighter-than-air machines in order to supplement the efforts of our fleet by machines which, in many respects and in favorable weather, are far more effective than the swiftest destroyer or the most powerful cruiser. Therefore we have done and are doing our best to dedevelop lighter-than-air machines."

These words are particularly interesting in view of a report which reached here last November, stating that Great Britain contemplated building 50 Zeppelins and other airships within two years, whereafter sufficient vessels would be laid down each year to insure complete mastery of the air. Provided this report is true, it will be interesting to watch the development of Great Britain's bid for aerial supremacy - and Germany's answer.

A Novel Device for Making Deviation Tests or Surveys in Deep Drill Holes (Concluded from page 642)

well defined image of the cross-hairs projected onto the disk of photographic paper at the other end of the tube by means of the objective lens, interposed at the proper focal distance between the cross-hairs and the paper. It is then merely a matter of analytic geometry to calculate the precise amount and direction of both dip and strike.

In plotting the points at which the readings are taken, it is assumed that the curvature of the hole is uniform between readings, and the coördinated distances as indicated on the paper disks from center of cross-hairs to vertical and horizontal diameters are considered as tangent offsets to the axis of the hole.

It is claimed that this instrument is well adapted for use in inclined holes as well as vertical ones, and as the general design is on the longitudinal plan, it is equally available for holes of small diameter. It is capable of a high degree of accuracy, because the methods by which the plottings are derived provides good geometrical leverage. It is independent of magnetic infiuences, and holds its adof magnetic infiuences, and holds its adjustment very well, being quite rugged in all its parts. It is well adapted to being lowered into the hole on a cable, except when there is great pressure of water in the hole, or when the hole is neardy horzontal or actually pointing upward. For such cases the form is modified. The
battery is placed within the tube, together with an automatic circuit maker and breaker which renders the apparatus entirely self-contained; and the instrument is then screwed to the drill rods.

Eliminating Railroad Accidents Arising from Faulty Switches (Concluded from page 642)

The lines of construction of the new switch are simple. Four full rails from 12 to 20 feet in length, according to the length of lead required, are arranged in two pairs. A train approaching for the main line is received on one rail of each pair and guided on to the regular main line rails A train approaching for the siding is received on the other rails of each pair and guided on to the regular siding rails. The heel of the switch is

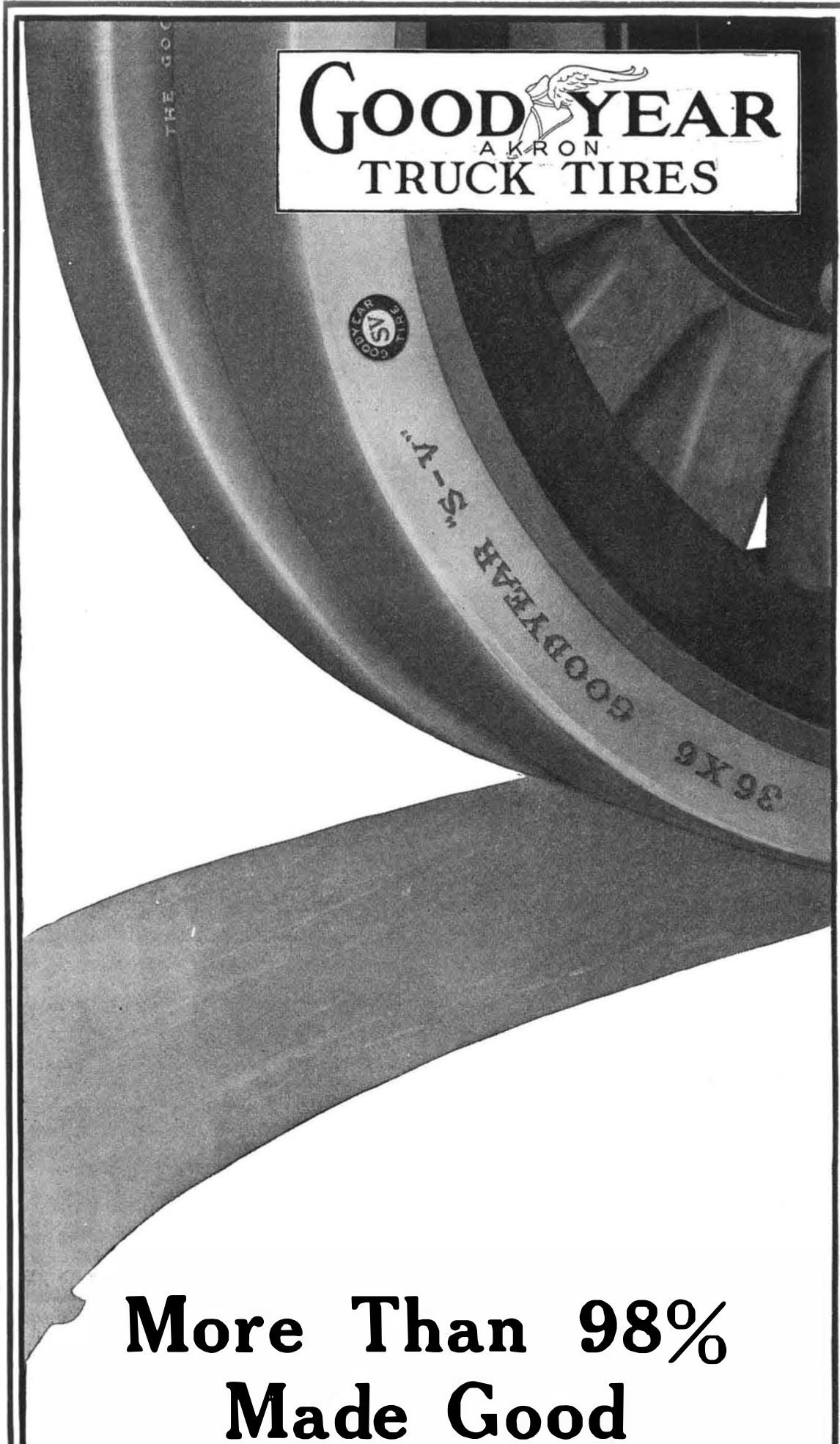

ROM April 1st, 1915, until Aprii 1st, A 1916, the Goodyear S-V was offered to the truck tire buyers of America on a "makegood" basis.

It was guaranteed to give a lower cost per mile than any other truck tire on an opposite wheel of the same truck. If the $S-V$ failed -its cost was to be refunded.

In spite of the fact that the tires would be subjected to various forms of abuse, we were certain that they would prove superior to any and every other truck tire in the market.

At the end of the test year of all the thousands of Goodyear S-V's sold on this basis more than $98 \%$ made good.

They had been tested against practically every known make of solid truck tire in the country-and more than $98 \%$ made good.

Isn't that pretty conclusive evidence that the Goodyear S-V assures truck tire buyers the characteristic Goodyear result-better service, longer mileage, and lower cost?

The nearest Goodyear Branch will be glad to submit to you the facts, figures and actual service records.

The Goodyear Tire \& Rubber Co., Akron, Ohio 